\title{
An evaluation of Employee Commitment of Part-Time Faculty (PTF) in Hong Kong's Continuing Professional Development (CPD) Sector
}

\author{
KS Li \\ Newcastle Graduate School of Business, University of Newcastle, Callaghan NSW, Australia \\ E-mail: likashu@gmail.com \\ Anthony Wong \\ Newcastle Graduate School of Business, University of Newcastle, Callaghan NSW, Australia \\ E-mail: awong@cihe.edu.hk \\ Canon Tong \\ International Graduate School of Business, University of Newcastle, Callaghan NSW, \\ Australia \\ E-mail: canon.tong@gmail.com
}

Accepted: Sep 19, 2013 Published: Oct 24, 2013

Doi:10.5296/ijhrs.v3i4.4447 URL: http://dx.doi.org/10.5296/ijhrs.v3i4.4447

\begin{abstract}
Economic crises in recent years have exposed the presence of a large number of poorly educated workers who can barely meet the needs of Hong Kong's knowledge-based economy. In response, in April 2002 the HKSAR Government set up a HK\$5 billion Continuing Education Fund to encourage and subsidize those who want to improve themselves through continuing education. This policy presents unprecedented opportunities for continuing professional development (CPD) course providers. To grasp these opportunities, they must act quickly to develop program mixes that match the education needs of potential students and demonstrate excellence in teaching quality by recruiting and retaining well-qualified faculty. As the majority of the courses are designed for those who seek to improve themselves after work, most of the courses are extramural courses conducted by part-time faculty (PTF). Recruitment of PTF raises an employee commitment problem which might affect their performance in teaching and also subsequently the effectiveness of those part-time courses. In addition, the various backgrounds of PTF also might affect the effectiveness of delivering of those CPD courses. So the objectives of this study are to examine the extent of employee commitment of those part-time staff and also the relations of their background towards the employee commitment. A quantitative study was used by applying Wang's (2004) five-component commitment model to test employee commitment of PTF in Hong Kong. An online questionnaire was used to collect sample data from a
\end{abstract}


population of PTF working at the 450 registered CPD course providers in Hong Kong. The data were analyzed and tested by means of factor analysis, correlation tests and structural equation modeling (SEM). Based on the data collected from 270 respondents, the study suggests that Wang's five-component model is better than other models for explaining employee commitment in Hong Kong's CPD industry. All five components of employee commitment of PTF and demographic variables were concluded to have no association with passive continuance commitment, but have varying levels of influences on different components of employee commitment.

\section{Introduction}

There has been a plethora of research in Europe and North America outlining the reasons why adults participate in formal learning activities (Mbokazi, Visser, and Fourie, 2007). Based on previous studies, a number of models concerning both teaching and learning for adult learners have been developed in the West. However, there has been very little comparable research in the Asian context to keep up with the growth of the phenomenon of continuing professional development (CPD). Therefore, research is needed to provide information to guide policy making on adult education in order to enhance the effectiveness of CPD teaching and learning in Asia. Fortunately, research into CPD is receiving attention in Hong Kong and most CPD institutions have the promotion and dissemination of CPD research as a major aim. In order to use human resources more economically and flexibly for providing relevant CPD courses, an institution needs to have access to a large team of part-time teaching staff. Jarvis $(2004 ; 1995)$ suggested that employment of such part-time faculty (PTF) is a characteristic of CPD. However, the various backgrounds of part-time staff and their commitment to their employers might a significant issue to study that might affect their quality of teaching of CPD courses.

\subsection{Background of the Study}

There are several reasons for instructors to undertake part-time teaching in CPD. These PTF can be the professionals who spend their leisure time teaching about their full-time jobs. They can also be full-time teachers who teach the discipline that they teach at school or college. In addition, some may even be passionate amateurs who teach what they learnt in the past while retaining their own full-time jobs (Lowe, 1982).

Studies undertaken by Weaver (2000) and Morton and Newman (1982) found that PTF of CPD programs are generally part-time and they may have more than one job. Similarly, Lowe (1982), in his discussion about the administration and organization of the teaching force in CPD, noted that the teaching of adults in CPD is overwhelmingly a part-time occupation largely carried out by people from a broad spread of professions other than teaching. Generally, PTF seem to be more vulnerable compared to full-time faculty when looked at in terms of conditions of service. Recruitment and employment procedures are often informal and ad hoc, and workers are often not given information about basic entitlements (Mezirow, 1991).

Apart from the heterogeneous and diverse backgrounds of PTF, there is the issue of female dominance of part-time CPD teaching. Lam (1992) recorded that $75 \%$ of the PTF listed in Hong Kong adult education prospectus were women. Similar findings are recorded from 
other research into CPD instructing. Dighe (1995) suggested that women have always constituted an important group of teachers in CPD programs.

Meyer and Allen's (1991) traditional three-component model has been widely applied for commitment studies in the PRC in the last two decades. However, due to cultural differences, the applicability of the model in a Chinese context was questioned by some researchers who proposed the addition of two sub-dimensions of continuance commitment to effectively make it a five-component commitment model. From the results of an empirical survey conducted in Guangdong, PRC, Wang (2004) found that a five-component model was more effective in explaining Chinese employment commitment than a traditional three-component model. Hong Kong employees may share a similar traditional culture to the people living in Guangdong due to their close proximity to one another. So the major focus of this study was to determine if employee commitment in Hong Kong can be explained by Wang's new model and whether their commitment to employers would be influenced by their backgrounds.

\section{Literature Review and Hypotheses Development}

Followings review employee commitment models and demographic variables as the important antecedents of employee commitment.

\subsection{Employee Commitment Theories Developed in the West}

According to Meyer, Stanley, Herscovitch and Topolnytsky (2002), and Meyer and Allen (1991), employee commitment ties the identity of a person to the organization becoming an attitude. Both employees and employers are in a process of sharing a common goal: the employees perceive rewards are sufficient to stay with the organization, and consider the costs associated with leaving the company to be too great; it is essentially a psychological state that reduces the rate of employee turnover and hence binds an employee to the organization.

Although there is no consensus on the definition of commitment, there is agreement among many researchers that a multidimensional construct should be viewed to commitment (Allen and Meyer, 1990; Mathiew and Zajac, 1990). Accordingly, by integrating attitudinal and behavioral commitments, Meyer and Allen (1991) classified commitment into the following three components: affective commitment (an individual's emotional attachment to the organization); continuance commitment (a result of the intention to stay with the organization in relation to the rewards for staying and the costs of leaving); and normative commitment (a feeling of obligation that an individual stays with the organization). Figure 1 illustrates Meyer and Allen's organizational model, which according to Wati (2005) has gained considerable popularity since its introduction. 


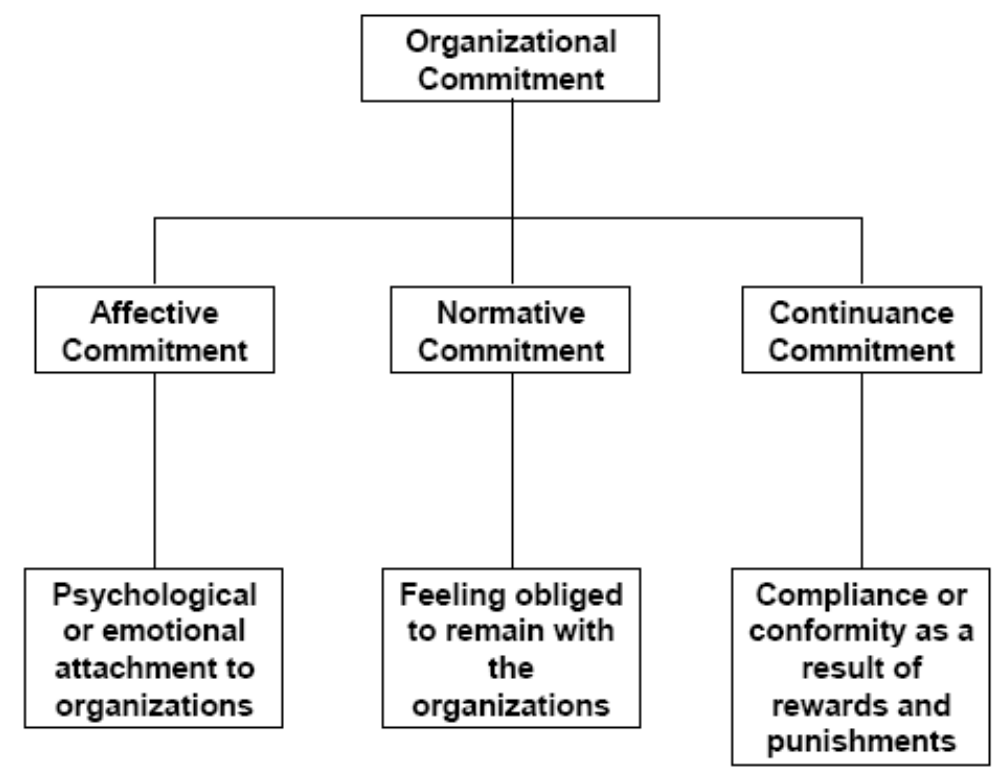

Figure 1 Meyer and Allen's three-component model of organizational commitment

According to Meyer and Allen (1991), affective, continuance, and normative commitments are psychological states that characterize employees' relationship with the organization and affect their decision whether to work with the organization.

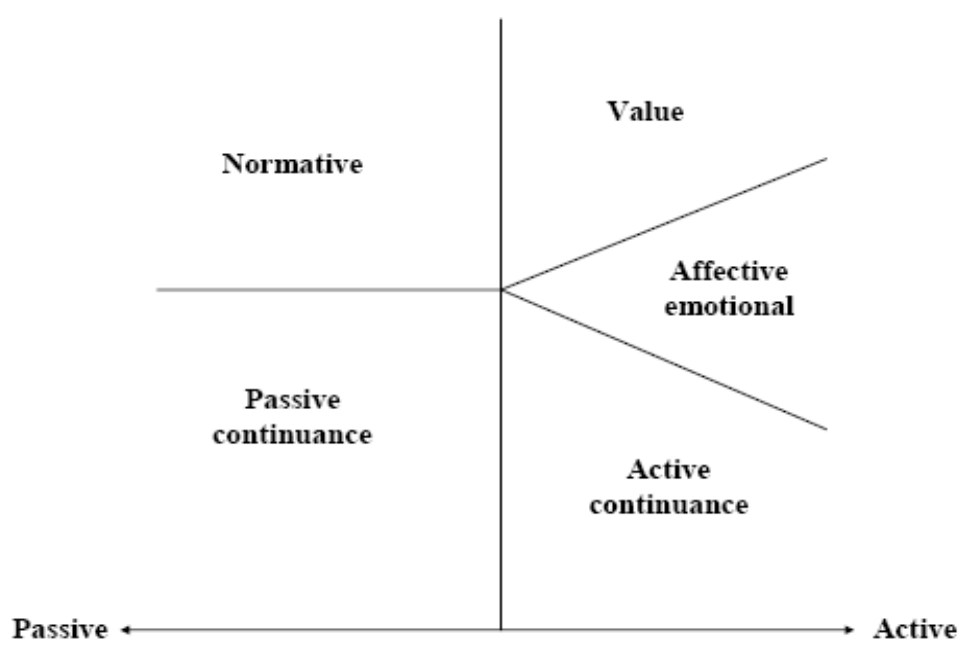

Figure 2 Wang's Five-component organizational commitment concept model

\subsection{Wang's Five-Component Commitment Model}

Ling, Fang and Zhang (2002) argued that there is variability from state to state due to cultural, social and institutional difference, which influences variations in employee commitment. On this basis, they claimed that commitment models developed in the West could not be generalized to PRC. Their studies of 1,500 PRC employees from different enterprises 
owned by Chinese used a five-component model modified from Meyer and Allen's (1991) three-component model. The five components are affective commitment, normative commitment, ideal commitment, economic commitment and choice commitment.

Following this study, Wang (2004) asserted that a unique organizational commitment phenomenon might exist in PRC and that models of commitment developed in the West would be insufficient to explain it in full. In 2002, Wang conducted a comparative study but using different components, in the Guangdong province, PRC based on Ling et al.'s (2002) model. The five components that Wang used were: value commitment, passive continuance commitment, affective commitment, normative commitment and active continuance commitment (Figure 2).

Affective commitment, which is widely used to measure emotional attachment, is identical to Meyer and Allen's (1991) model. Continuance commitment is divided into active and passive commitments as strongly supported by many others researchers (Iverson and Buttigieg, 1999). Active continuance commitment represents motivation induced by the availability of promotion opportunities and on-the-job training, which is different from the traditional high-sacrifice/low-alternative continuance commitment. Passive continuance commitment represents the traditional type of continuance commitment whereby an employee chooses to stay with the organization because she or he is unable to find another job. Normative commitment, which is the same as in Meyer and Allen's (1991) three-component model, represents staying with the organization with a sense of obligation. A feeling of moral obligation to stay with the organization will happen to an employee with a high level of normative commitment. For example, an employer's MBA degree sponsorship recipient may be obliged to stay with the organization. Value commitment, which is excluded in Meyer and Allen's (1991) model, refers to an employee's willingness to make a significant effort for the benefit of organization (Wang, 2004). An employee who has been working for the same organization for many years usually develops an emotional attachment to it but this does not guarantee that he or she will work hard. There is no guarantee that the employee will work hard even working with the same employer for many years because they are merely emotionally attached to the organization.

Even though Wang's model developed for this study has yet to be validated for use in PRC due to the diverse culture among provinces in its north and south, it was nevertheless adopted for this study in terms of its appropriateness and high relevancy in a PRC society. Because Guangdong province is geographically close to Hong Kong, people living in these two areas might share certain common traditional cultures and values, despite the study by Snape and Chan (2000) demonstrating that Hong Kong employees' commitment is more alike to those in West. However, a study by Chui, Tong and Mula (2007) on ICT professionals in Hong Kong found that the five-component commitment model was better than the traditional three-component model for explaining employee commitment.

The fifteen-item commitment framework developed by Mowday, Steers and Porter (1979) has been widely used to measure employee commitment, as has the three-component commitment model developed by Meyer and Allen (1991). However, Wang's (2004) study in Mainland China provided compelling evidence to suggest that in a PRC context the five-component commitment model is a better predictor. With over ninety percent of Hong 
Kong's population being Chinese, it is appropriate to test whether Wang's relatively new five-component commitment model is more appropriate in a Hong Kong context to better understand and explain employee commitment in comparison to the three- and four-component models. It was therefore hypothesized that:

Hypothesis 1: Wang's (2004) five-component commitment model is a better measure than the three-component model by Meyer and Allen (1991) and the four-component model by Ling et al. (2002), of employee commitment of PTF in Hong Kong.

\subsection{Demographic Variables}

One important antecedent to continuance commitment is demographics such as tenure, gender and age. Younger employees tend to be less affectively committed than older employees and a significant predictor of normative commitment is age (Meyer and Smith, 2000; Taormina, 1999). However, findings from research carried out on organizational commitment in Shanghai and Guangzhou suggested that there is no relationship between demographics and organizational commitment in PRC (Chen and Francesco, 2000). The researchers suggested that this could be caused by culture differences and the inter-personal relationship effect, known as Guanzi, which greatly influences PRC society.

Many studies have found demographic variables such as tenure, gender, and age with an organization to be the antecedents of employee commitment (Meyer et al., 2002; Hackett, Bycio and Hausdorf, 1994). Thus the sign either with positive or negative of the correlation is yet to be identified. To determine whether the demographic variables can be the antecedent variables to employee commitment, it was hypothesized that:

Hypothesis 2: Demographic variables of PTF in Hong Kong are significantly correlated with employee commitment components (value, passive continuance, affective, normative and active continuance commitments).

\subsection{Research Model}

The research model for this study is presented in Figure 3. Employee commitment, as the dependent construct, was adopted from Wang (2004) and comprises of five components or factors: value commitment, active continuance, effective commitment, normative continuance and passive continuance. Demographic characteristics of employees have been shown to affect the level of commitment employees have towards their organizations. Thus demographic variables have been treated as independent variables in the model to see which of these variables have an effect on employee commitment of PTF in Hong Kong. 


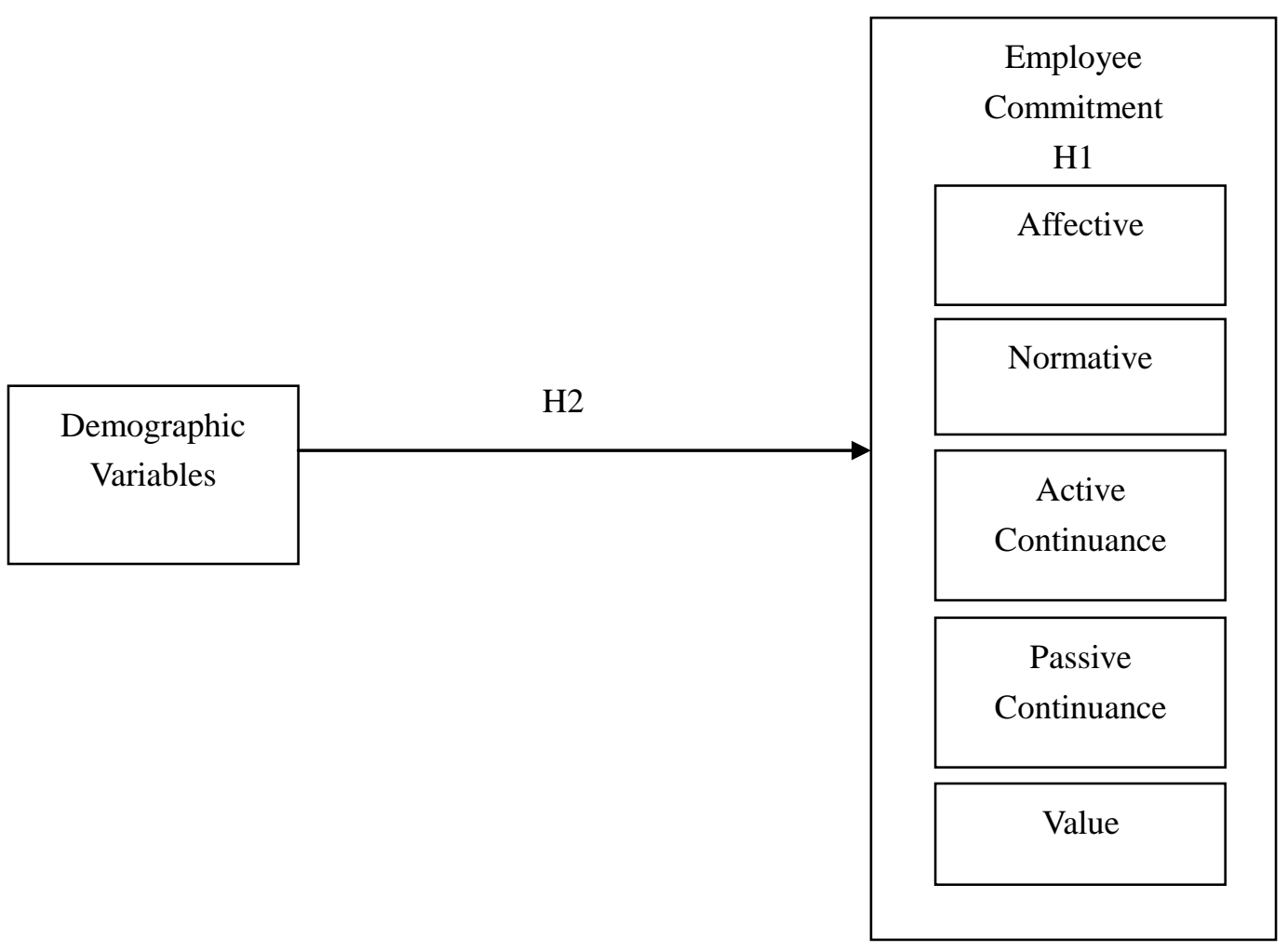

Figure 3 Research Model

\section{Methodology}

\subsection{Sample}

Random sampling technique was used because it is the most common and easiest way to ensure that bias is minimized (Bryman, 2008). Randomly selected 50 course providers are requested to distribute invitations to fellow PTF, who are requested to complete a self-administered anonymous web-based questionnaire survey via a hyperlinked website. As a result of this request, around 2,500 PTF from 50 randomly selected major CPD course providers were approached by their employers. Finally data were collected from 270 respondents.

\subsection{Research Instruments}

Demographic profiles of respondents were developed from age, nationality (used for qualifying purpose), education level, tenure with the current company, requirement for business trip, gender, personal income, marital status, number of working hours per week and job involvement.

The questions used to measure employee commitment were adopted from Wang's (2004) model and are listed in Table 1. There were no fundamental modifications made to these attributes because one of the objectives of this study was to determine the generalizability of this five-component model to Hong Kong.

There are three questions used to measure affective commitment that were adopted from Wang's study. In eight continuance commitment items, five are for measuring active continuance commitment and three are passive continuance commitment, which were adopted from Ling et al.'s (2002) scales. Three questions were adopted from Wang's study to measure normative commitment, and among of the four questions used for measuring 
value commitment, two were adopted from Wang and two from Ling et al.'s scales.

\begin{tabular}{|c|c|c|}
\hline Construct & Item & Questions \\
\hline \multirow{4}{*}{$\begin{array}{l}\text { Affective } \\
\text { Commitment }\end{array}$} & $\mathrm{AC} 1$ & I am extremely glad that I chose this Institution to work \\
\hline & & for over others I was considering at the time I joined \\
\hline & $\mathrm{AC} 2$ & $\begin{array}{l}\text { I talk up this Institution to my friends as a great to work } \\
\text { for }\end{array}$ \\
\hline & AC3 & I am proud to tell others that I am part of this Institution \\
\hline \multirow{6}{*}{$\begin{array}{l}\text { Continuance } \\
\text { Commitment } \\
\text { (active) }\end{array}$} & CA1 & I work for the Institution because it provides me witl \\
\hline & & many on-the-job training opportunities \\
\hline & CA2 & $\begin{array}{l}\text { I work for the Institution because it is a good chance to } \\
\text { realize my goals }\end{array}$ \\
\hline & CA3 & $\begin{array}{l}\text { I work for the Institution because I can make full use of } \\
\text { what I have learned here }\end{array}$ \\
\hline & CA4 & I work for the Institution because of the challenging job \\
\hline & CA5 & $\begin{array}{l}\text { I work for the Institution because there are many } \\
\text { opportunities for promotion }\end{array}$ \\
\hline \multirow{3}{*}{$\begin{array}{l}\text { Continuance } \\
\text { Commitment } \\
\text { (passive) }\end{array}$} & CP1 & $\begin{array}{l}\text { I work for the Institution because I cannot find a better } \\
\text { one }\end{array}$ \\
\hline & $\mathrm{CP} 2$ & $\begin{array}{l}\text { I cannot quit the job arbitrarily because I have to support } \\
\text { my family }\end{array}$ \\
\hline & CP3 & $\begin{array}{l}\text { I work for the Institution because I do not want to lose my } \\
\text { fringe benefits }\end{array}$ \\
\hline \multirow[t]{3}{*}{$\begin{array}{l}\text { Normative } \\
\text { Commitment }\end{array}$} & $\mathrm{NC} 1$ & $\begin{array}{l}\text { I consider it my obligation to work for the same } \\
\text { Institution all the while }\end{array}$ \\
\hline & $\mathrm{NC} 2$ & I would like lifetime employment if possible \\
\hline & NC3 & I would do any job as long as I work here \\
\hline \multirow[t]{4}{*}{$\begin{array}{l}\text { Value } \\
\text { Commitment }\end{array}$} & $\mathrm{VC} 1$ & $\begin{array}{l}\text { I am willing to put in a great deal of effort beyond that } \\
\text { normally expected in order to help this Institution to be } \\
\text { successful }\end{array}$ \\
\hline & $\mathrm{VC} 2$ & I really care about the fate of this Institution \\
\hline & VC3 & $\begin{array}{l}\text { This Institution really inspires me to do my job to the very } \\
\text { best of my abilities }\end{array}$ \\
\hline & $\mathrm{VC} 4$ & One should work with utmost efforts for the Institution \\
\hline
\end{tabular}

Table 1 Instruments for Measuring Employee Commitment

\subsection{Data Analysis}

Data analysis in this study includes checking of validity and reliability of measuring scales and structural equation modeling and correlation were used for testing the hypotheses. Items for measuring employee commitment were from Wang (2004) and all of the questionnaire items for this study were adapted from peer reviewed articles and the same measuring scales had already been adapted or adopted by relevant previous studies, it was reasonable to assume that both content and construct validities of the measures and scales have been validated already. To further increase the quality of this study, statistical techniques, Cronbach's alpha and factor analysis were used to check for data validity and reliability. Cronbach's alpha coefficients were used to estimate the reliability of each of latent variables by checking the internal consistency of the observable variables concerned. Factor analysis 
techniques, i.e., principle component analysis and varimax rotation were adopted to check for uni-dimensionality of the measuring items for employee commitment in the questionnaire (Coakes, Steed and Price, 2008; Caceres and Paparoidamis, 2007). Prior to the performance of hypotheses testing, each of the latent variables was computed by weighting the factor loading of its corresponding measuring items (Sivadas, Kleiser, Kellaris and Dahlstrom, 2003). Measuring items with low factor loading weights were removed to ensure the quality of data analysis undertaken (Karakaya and Barnes, 2010). Structural equation modeling (SEM) was used to determine whether Wang's (2004) five-component model was a better fit than the four-component model (Ling et al., 2002) and three-component model (Meyer and Allen 1991) in explaining employee commitment of PTF in Hong Kong's CPD industry. Second-order factor analysis was conducted for all three models using SEM modeling. The model fit indices returned were used to judge which one of the three models was the best fit. The model with the lowest Chi-square per degrees of freedom as well as the highest goodness-of-fit index (GFI) and comparative fit index (CFI) are considered the best fit (Arbuckle, 2009). Correlation matrix was calculated to examine the relationships among demographic variables and employee commitment variables.

\section{Findings}

\subsection{Characteristics of the Sample}

Table 2 summarizes the key demographic variables of the research.

\begin{tabular}{llrr} 
Demographic Variables & Measures & Frequency & Percentage \\
\hline Working hours & Below 40 hours & 27 & $10.0 \%$ \\
Per week & $40-40$ hours & 82 & $30.4 \%$ \\
& $50-59$ hours & 135 & $50.0 \%$ \\
\hline Time spent on & $60+$ hours & 26 & $9.6 \%$ \\
business trips & No business travelling required & 132 & $48.9 \%$ \\
& No more than 25\% of time & 55 & $20.4 \%$ \\
& $25 \%-50 \%$ & 29 & $10.7 \%$ \\
& $51 \%-75 \%$ & 28 & $10.4 \%$ \\
Tenure & Over 75\% of the time & 26 & $9.6 \%$ \\
& 5 years or less & 118 & $43.7 \%$ \\
& $6-10$ years & 84 & $31.1 \%$ \\
& $11-15$ years & 57 & $21.1 \%$ \\
& $16-20$ years & 10 & $3.7 \%$ \\
Teaching Level & $21-25$ years & 1 & $0.4 \%$ \\
& Non-graduate & 122 & 45. \\
& Graduate & 66 & $24.3 \%$ \\
& Post-graduate & 81 & $30.1 \%$ \\
Gender & Doctorate & 1 & $0.5 \%$ \\
\hline Age & Female & 130 & $48.1 \%$ \\
& Male & 140 & $51.9 \%$ \\
\hline & below 25 & 0 & $0.0 \%$ \\
& 26-30 & 11 & $4.0 \%$ \\
& 31 - 35 & 58 & $21.5 \%$
\end{tabular}




\begin{tabular}{llrr}
\hline & $36-40$ & 64 & $23.7 \%$ \\
& $41-45$ & 69 & $25.6 \%$ \\
& 46 and above & 68 & $25.2 \%$ \\
\hline Nationality & Local HK Chinese & 270 & $100.0 \%$ \\
& Others & 0 & $0.0 \%$ \\
\hline Marital Status & Single & 108 & $40.0 \%$ \\
& Married & 162 & $60.0 \%$ \\
\hline Level of Education & Non-Graduate & 14 & $5.2 \%$ \\
& Graduate & 52 & $19.3 \%$ \\
& Post-Graduate & 173 & $64.8 \%$ \\
& Doctorate & 22 & $8.1 \%$ \\
& Post-Doctorate & 7 & $2.6 \%$ \\
\hline Monthly Income & Under $\$ 10,000$ & 2 & $0.7 \%$ \\
& \$10,000 - \$19,999 & 12 & $4.5 \%$ \\
& \$20,000 - \$29,999 & 62 & $23.0 \%$ \\
& \$30,000 - \$39,999 & 84 & $31.1 \%$ \\
& $\$ 40,000-\$ 49,999$ & 67 & $24.8 \%$ \\
& $\$ 50,000$ and above & 43 & $15.9 \%$ \\
\hline
\end{tabular}

Table 2 Characteristics of the Sample

\subsection{Validity and Reliability}

The survey data collected were analyzed with Cronbach's alpha test. A Cronbach's alpha value of 0.60 or above is regarded as having an acceptable level of reliability while a Cronbach's alpha value of 0.70 or above is regarded as desirable (Coakes et al., 2008; Malhotra, 2006; Shin, Collier and Wilson, 2000; Nunnally, 1989). Table 3 summarizes the Cronbach's alpha values of the factors. The factors have a Cronbach's alpha value between 0.877 and 0.907 and are, therefore, all considered acceptable in terms of reliability. Although some may appear high, using validated measures and instruments can provide such alpha values. A high value of alpha (>0.90) may suggest redundancies and show that the test length should be shortened (Streiner, 2003).

Factors Cronbach's Alpha Number of Items

Affective Commitment

Active Continuance Commitment

Passive Continuance Commitment

Normative Commitment

Value Commitment

Overall Commitment

$\begin{array}{ll}0.880 & 3 \\ 0.877 & 5 \\ 0.878 & 3 \\ 0.899 & 3 \\ 0.907 & 4 \\ 0.879 & 5\end{array}$

Table 3 Cronbach's Alpha

\subsection{Factor Analysis}

The following section describes the observed variables as measured by the questionnaire items and the latent variables found by factor loadings. Prior to the performance of hypotheses testing, each of the latent variables was calculated from the factor loading weighting of its corresponding measuring items (Sivadas et al., 2003). 


\subsubsection{Perception of Commitment}

Table 4 below shows the factor loadings on the five components of and overall employee commitment. All items successfully loaded on their respective factors.

\begin{tabular}{|c|c|c|}
\hline Items & Questions & Loading \\
\hline $\mathrm{AC} 1$ & $\begin{array}{l}\text { I am extremely glad that I chose this Institution to } \\
\text { work for over others I was considering at the time I joined }\end{array}$ & 0.718 \\
\hline $\mathrm{AC} 2$ & I talk up this Institution to my friends as a great to work for & 0.685 \\
\hline AC3 & I am proud to tell others that I am part of this Institution & 0.67 \\
\hline CA1 & $\begin{array}{l}\text { I work for the Institution because it provides me with } \\
\text { many on-the-job training opportunities }\end{array}$ & 0.639 \\
\hline CA2 & $\begin{array}{l}\text { I work for the Institution because it is a good chance to } \\
\text { realize my goals }\end{array}$ & 0.612 \\
\hline CA3 & $\begin{array}{l}\text { I work for the Institution because I can make full use } \\
\text { of what I have learned here }\end{array}$ & 0.644 \\
\hline CA4 & I work for the Institution because of the challenging job & 0.625 \\
\hline CA5 & $\begin{array}{l}\text { I work for the Institution because there are many } \\
\text { opportunities for promotion }\end{array}$ & 0.623 \\
\hline CP1 & I work for the Institution because I cannot find a better one & 0.695 \\
\hline $\mathrm{CP} 2$ & $\begin{array}{l}\text { I cannot quit the job arbitrarily because I have to support } \\
\text { my family }\end{array}$ & 0.747 \\
\hline $\mathrm{CP} 3$ & $\begin{array}{l}\text { I work for the Institution because I do not want to lose my } \\
\text { fringe benefits }\end{array}$ & 0.763 \\
\hline $\mathrm{NC} 1$ & $\begin{array}{l}\text { I consider it my obligation to work for the same Institution } \\
\text { all the while }\end{array}$ & 0.708 \\
\hline $\mathrm{NC} 2$ & I would like lifetime employment if possible & 0.683 \\
\hline NC3 & I would do any job as long as I work here & 0.652 \\
\hline $\mathrm{VC1}$ & $\begin{array}{l}\text { I am willing to put in a great deal of effort beyond that } \\
\text { normally expected in order to help this Institution to be } \\
\text { successful }\end{array}$ & 0.728 \\
\hline $\mathrm{VC} 2$ & I really care about the fate of this Institution & 0.760 \\
\hline VC3 & $\begin{array}{l}\text { This Institution really inspires me to do my job to the } \\
\text { very best of my abilities }\end{array}$ & 0.673 \\
\hline VC4 & One should work with utmost efforts for the Institution & 0.763 \\
\hline $\mathrm{OC} 1$ & I intend to stay with my Institution for the next several years & 0.754 \\
\hline OC2 & $\begin{array}{l}\text { I would stay with my Institution even if offered a } \\
\text { comparable job elsewhere at slightly higher pay }\end{array}$ & 0.772 \\
\hline OC3 & I would recommend my Institution as a good place to work & 0.777 \\
\hline OC4 & I am proud to be associated with my Institution & 0.773 \\
\hline OC5 & $\begin{array}{l}\text { Considering everything, I am very satisfied with my job } \\
\text { in my Institution }\end{array}$ & 0.758 \\
\hline
\end{tabular}

Table 4 Factor Loadings on Perception of Commitment

\subsection{Hypotheses Testing}

The hypotheses developed were tested to validate the research model in this study.

\subsubsection{Wang's Five-component Commitment Model}

Hypothesis 1: Wang's (2004) five-component commitment model is a better measure than 
the three-component model by Meyer and Allen (1991) and the four-component model by Ling et al. (2002), of employee commitment of PTF in Hong Kong.

Wang (2004) proposed a five-component commitment model and the results in her study proved that the five-component model fitted the data of the study better than the traditional three-component model by Meyer and Allen (1991) and the four-component model by Ling et al. (2002). For this study, the same approach that Wang (2004) used to compare the validity of each multidimensional structure was employed, and the results used to determine whether the first hypothesis has to be rejected.

Confirmatory factor analysis is used to test this hypothesis. In this study, the three multi-dimensional commitment models were pre-established and compared by using confirmatory factor analysis which is shown in Table 5.

Structural equation modeling (SEM) model fit indices was used to determine which model is better fit for PTF in Hong Kong's CPD sector. From Table 5, $\operatorname{CMIN}\left(\chi^{2}\right)$ for the 5-factor model is 591.802, which is much lower than that of the 3-factor model and 4-factor model (966.799 and 1227.932), indicating the 5-factor model appears to be a better fit than the other two models. CMIN/DF $\left(\chi^{2} / \mathrm{df}\right)$ ratio for the 5-factor model is 4.552 , which is much lower than that of the 3-factor model and 4-factor model (13.065 and 9.374 respectively), indicating the 5-factor model appears to be a better fit than the other two models. Moreover, the Goodness-of-fit Index (GFI) and Comparative Fit Index (CFI) of the 5-factor model are 0.866 and 0.967 respectively, which are higher than that of the other two models, indicating that the 5 -factors model is a better fit than the other two models in terms of both GFI and CFI. Therefore, Hypothesis 1 is supported.

\begin{tabular}{lclllcll} 
Model & NPAR & CMIN $\left(\chi^{2}\right)$ & df & P & CMIN/DF & GFI & CFI \\
\hline 3-factor model & 31 & 966.779 & 74 & .000 & 13.065 & .786 & .908 \\
4-factor model & 40 & 1227.932 & 131 & .000 & 9.374 & .779 & .921 \\
5-factor model & 41 & 591.802 & 130 & .000 & 4.552 & .866 & .967 \\
\hline
\end{tabular}

Table 5 Model Fit Summary

\subsubsection{Demographic Variables of PTF in Hong Kong}

Hypothesis 2: Demographic variables of PTF in Hong Kong are significantly correlated with employee commitment components (affective, active continuance, passive continuance, normative and value commitments).

The correlation statistics in Table 6 shows that gender, monthly income, educational level and marital status are not significantly correlated with any of the factors of employee commitment. On the other hand, age was found to have a significant negative correlation with affective commitment $(\mathrm{r}=-0.119, \mathrm{p}<0.05)$, active continuance commitment $(\mathrm{r}=-0.103$, $\mathrm{p}<0.05)$ and value commitment $(\mathrm{r}=-0.105, \mathrm{p}<0.05)$. Analysis shows that "working hours per week", "percentage of time for business trip", "tenure" and "job involvement" have significant correlation with all factors of employee commitment except passive continuance commitment $(\mathrm{CP})$. With five out of nine demographic variables having significant negative associations with four out of the five factors of employee commitment, Hypothesis 2 is partially supported. 


\begin{tabular}{|c|c|c|c|c|c|c|}
\hline & & $\mathrm{AC}$ & CA & $\mathrm{CP}$ & $\mathrm{NC}$ & VC \\
\hline \multirow[t]{3}{*}{ Gender } & $\begin{array}{l}\text { Pearson } \\
\text { Correlation }\end{array}$ & .017 & -.011 & -.020 & -.016 & -.017 \\
\hline & Sig. (2-tailed) & .735 & .822 & .685 & .750 & .724 \\
\hline & $\mathrm{N}$ & 412 & 412 & 412 & 412 & 412 \\
\hline \multirow[t]{3}{*}{ Age } & $\begin{array}{l}\text { Pearson } \\
\text { Correlation }\end{array}$ & $-.119(*)$ & $-.103(*)$ & -.009 & -.094 & $-.105(*)$ \\
\hline & Sig. (2-tailed) & .015 & .037 & .860 & .056 & .034 \\
\hline & $\mathrm{N}$ & 412 & 412 & 412 & 412 & 412 \\
\hline \multirow[t]{3}{*}{ Monthly Income } & $\begin{array}{l}\text { Pearson } \\
\text { Correlation }\end{array}$ & -.068 & -.082 & -.002 & -.081 & -.082 \\
\hline & Sig. (2-tailed) & .171 & .097 & .971 & .102 & .095 \\
\hline & $\mathrm{N}$ & 412 & 412 & 412 & 412 & 412 \\
\hline \multirow{3}{*}{$\begin{array}{l}\text { Educational } \\
\text { Level }\end{array}$} & $\begin{array}{l}\text { Pearson } \\
\text { Correlation }\end{array}$ & -.067 & -.070 & -.020 & -.066 & -.074 \\
\hline & Sig. (2-tailed) & .174 & .155 & .691 & .181 & .135 \\
\hline & $\mathrm{N}$ & 412 & 412 & 412 & 412 & 412 \\
\hline \multirow[t]{3}{*}{ Marital Status } & $\begin{array}{l}\text { Pearson } \\
\text { Correlation }\end{array}$ & -.081 & -.066 & -.023 & -.073 & -.090 \\
\hline & Sig. (2-tailed) & .101 & .180 & .639 & .138 & .067 \\
\hline & $\mathrm{N}$ & 412 & 412 & 412 & 412 & 412 \\
\hline \multirow{3}{*}{$\begin{array}{l}\text { Working Hours } \\
\text { per week }\end{array}$} & Pearson & $-.231(* *$ & $-.236(* *$ & -.043 & $-.233(* *$ & $-.241(* *$ \\
\hline & $\begin{array}{l}\text { Correlation } \\
\text { Sig. (2-tailed) }\end{array}$ & $\begin{array}{r}\text { ) } \\
.000\end{array}$ & $\begin{array}{r}\text { ) } \\
.000\end{array}$ & .380 & $\begin{array}{r}\text { ) } \\
.000\end{array}$ & $\begin{array}{r}\text { ) } \\
.000\end{array}$ \\
\hline & $\mathrm{N}$ & 412 & 412 & 412 & 412 & 412 \\
\hline \multirow{4}{*}{$\begin{array}{l}\text { Percentage of } \\
\text { Time for } \\
\text { Business Trip }\end{array}$} & Pearson & $-.130(* *$ & $-.135(* *$ & & $-.148(* *$ & $-.144(* *$ \\
\hline & Correlation & & ) & -.015 & ) & ) \\
\hline & Sig. (2-tailed) & .008 & .006 & .759 & .003 & .003 \\
\hline & $\mathrm{N}$ & 412 & 412 & 412 & 412 & 412 \\
\hline \multirow[t]{4}{*}{ Tenure } & Pearson & $-.140(* *$ & $-.140(* *$ & .008 & $-.131(* *$ & $-.139(* *$ \\
\hline & Correlation & & & & & \\
\hline & Sig. (2-tailed) & .005 & .005 & .875 & .008 & .005 \\
\hline & $\mathrm{N}$ & 412 & 412 & 412 & 412 & 412 \\
\hline \multirow[t]{4}{*}{ Job Involvement } & Pearson & $-.199(* *$ & $-.217(* *$ & -.059 & $-.214(* *$ & $-.216(* *$ \\
\hline & Correlation & & & & & \\
\hline & Sig. (2-tailed) & .000 & .000 & .232 & .000 & .000 \\
\hline & $\mathrm{N}$ & 412 & 412 & 412 & 412 & 412 \\
\hline
\end{tabular}

* Correlation is significant at the 0.05 level (2-tailed).

Table 6 Correlations between Demographic Variables and components of Employee Commitment of PTF in Hong Kong (H2)

\section{Discussion}

Wang's (2004) model was found to be better than the four-component model and three-component model in explaining employee commitment of PTF in Hong Kong. The SEM model fit indices showed that the CMIN/DF $(\chi 2 / \mathrm{df})$ ratio for the five-component model (Wang, 2004) was 4.552, which is much lower than the relevant ratios of the three-component 
model's (13.065) and four-component model's (9.374), demonstrating that the five-component model is a better fit than the other two models. Moreover, the Goodness-of-fit Index (GFI) and Comparative Fit Index (CFI) of the five-component model were 0.866 and 0.967 respectively, which are higher than that of the other two models, providing further evidence that the five-component model is a better fit than the other two models. The results give support to the hypothesis that Wang's five-component commitment model is better than the three-component model (Meyer and Allen. 1991) and the four-component model (Ling et al., 2002) in explaining employee commitment of PTF in Hong Kong.

The demographic results revealed that all of the participants in this study were local Hong Kong Chinese and that $45.1 \%$ of them were teaching non-graduate courses. The demography of the study's respondents is similar to that gathered from the study of IT professionals reported by Chui et al. (2007) in terms of the number of hours worked each week, time spent on business trips and tenure. The majority of respondents to both studies were working 50 or more hours per week; $59 \%$ in Chui et al.'s study and $59.6 \%$ in this study, the latter reflecting the trend of increasing working hours following the global financial crisis (GFC). The majority of respondents to both studies were not required to go on business trips; $61 \%$ in Chui et al.'s (2007) study and close to half in this study, again possibly reflecting the effects of the GFC. Most respondents to both studies had tenure of less than 5 years; IT professionals tend to change jobs frequently (65\% in Chui et al.'s, 2007) but part time teaching staff does as well $(43.7 \%)$.

However, in the aspects of age, monthly income, educational level and marital status, there are some considerable differences between this study and that of Chui et al.'s (2007). The differences can be partly explained by the difference of the industries involved. Unlike Chui et al.'s study, in which most of the respondents were male (70\%) and single (59\%), this study had almost equal distribution of males and females, with $51.9 \%$ respondents male and $48.1 \%$ female. The IT sector is dominated by males who are in their early career stage, thus single, whereas PTF tend to be at a more mature stage of their career and they can mix bringing up a family with part-time work. Some $60 \%$ of the respondents of this study were married, while the number of married respondents in Chui et al.'s only accounted for $41 \%$ of the total.

The monthly incomes and levels of education of the participants in this study were, in general, higher than those in Chui et al.'s (2007) study. The ages of the respondents in this study were, in general, older than those in Chui et al.'s (2007) reflecting a more mature career stage. The age distribution of PTF revealed that there was an almost even distribution of respondents across the 26 to 45 age groups. The percentages of respondents in the age groups of 26-30, 31-35, 36-40 and 41-45 were $21.4 \%, 23.5 \%, 25.7 \%$ and $25.5 \%$, respectively. However, in Chui et al.'s study, most of the respondents were in the age groups of 26-30 and $31-35$ (32\% and 33\% respectively), again mirroring the dominance of younger early career professionals.

In the main, most demographic variables were found to have no association with passive continuance commitment. Gender, monthly income, educational level, and marital status have no association with any of the factors of employee commitment. But hours worked per week, time spent on business trips, tenure and job involvement were found to have significant 
negative associations with the remaining four components of employee commitment $(\mathrm{R}$ in the range of -0.103 to $-0.241, \mathrm{p}<0.05)$. Moreover, age was found to be significantly negatively associated with affective commitment $(\mathrm{R}=-0.119, \mathrm{p}<0.05)$, active continuance commitment $(\mathrm{R}=-0.103, \mathrm{p}<0.05)$ and value commitment only $(\mathrm{R}=-0.105, \mathrm{p}<0.05)$. The negative associations could be interpreted as the larger the variable such as longer hours or greater time spent on business trips, the less PTF are committed to institutions in Hong Kong. This is irrespective of gender, marital status, income, tenure or education level. This gives partial support to the hypothesis that demographic characteristics of PTF in Hong Kong are significantly associated with employee commitment.

\section{Implications}

\subsection{Academic Contributions}

This study contributes to some aspects of employee commitment research. Firstly, most of the previous human resource management literature is focused on psychological contract; little research has been undertaken on employee commitment (Malhotra, Budhwar and Prowse, 2007). This study reveals that commitment models developed for Western settings, such as the one of Meyer and Allen (1991), were not as effective as Wang's (2004) five-component model in addressing the issue of employee commitment in a Chinese setting. Moreover, as only a limited number of employee commitment studies have been conducted with specific reference to Chinese settings thus far, this study highlights the need for the development of an employee commitment model that addresses a context which is predominately Chinese. It was also found that different demographic characteristics have different impacts on different components of employee commitment.

Although the sample size is 270 of this study which is smaller than similar studies (Chui et al., 2007; Wang, 2004), but the findings are focused on the CPD industry in Hong Kong and may only be valid to that specific industry and place researched. This difference may signal that though the five-component model is found to be the better fit in studying employee commitment in a Chinese setting, further modification might be needed in order to make the findings more generalizable to other Chinese-dominant countries and industries.

\subsection{Management Implications}

Apart from the theoretical contributions, the findings of this study also reveal a number of management implications. The presence of a negative correlation between hours worked per week and employee commitment highlights that PTF with shorter working hours have higher employee commitment. The finding suggests that CPD institutes can enhance overall commitment of their PTF by leveraging hours worked in other jobs. If possible, preference can be given to those who work shorter hours in their full time jobs. In addition, the negative correlation between the percentage of time spent on business trips and employee commitment indicates that PTF who were not required to travel had higher commitment. The finding suggests that, if possible, CPD institutes can enhance overall employee commitment of their PTF by recruiting staffs who are not required to travel or who only need to do a little travel in their full-time jobs. Last but not the least, the negative correlation between tenure and employee commitment indicates that PTF with shorter tenure had higher employee commitment. The finding suggests that turnover might not be a bad thing for CPD institutes 
after all.

\section{Limitations and Future Research}

This study has the following limitations which may hinder generalizability of the findings. Data were collected by means of questionnaires. Thus, information on items such as PTF's characteristics was subject to the influences of personal perceptions and the honesty of individuals. In addition, data were only gathered from PTF, not from others who might comment on them such as CPD supervisors and students. The information generated therefore only reflected the perceptions of PTF.

The sample size did not embrace all of the population and therefore individuals working in a variety of settings and specific minority groups could be missing. The study utilised a sample of 270 PTF from 50 random selected CPD institutions in Hong Kong. A larger sample will produce more reliable results for generalizations over the entire population of CPD PTF in Hong Kong.

Last but not least, the results of this study were based on data from respondents who were willing to return their questionnaires. Those who were unwilling to respond may be either dissatisfied or apathetic. Therefore, the results computed here may be an overestimation of employee commitment among the population. Perhaps, personal interviews with those PTF who have quit their jobs could be valuable for collecting additional information about the commitment to their companies.

There are many opportunities for further research to overcome the limitations identified above. Future research can be conducted using a mixed-method approach to leverage the advantages of both quantitative and qualitative methods. While qualitative methods can be used to identify more antecedents of employee commitment of PTF in the CPD industry and develop relevant hypotheses, quantitative methods can be applied to empirically test the hypotheses with a large sample size and on a population that includes full-time faculty.

\section{References}

Arbuckle, J. L. (2009), Amos 18 user's guide. Amos Development Corporation.

Bryman, A. (2008), Social research methods, New York: Oxford University Press.

Caceres, R. C., and Paparoidamis, N. G. (2007), Service quality, relationship satisfaction, trust, commitment and business-to-business loyalty, European Journal of Marketing, 41(7), 836-867.

Chen, Z. X., and Francesco, A. M. (2000), Employee demography, organizational commitment, and turnover intentions in China: Do cultural differences matter? Human Relations, 53(6), 869-887.

Chui, J., Tong, C. and Mula, J. M. (2007), Career development impacting commitment, $\underline{\text { 18th }}$ Australasian Conference on Information Systems, 5-7 Dec 2007, Toowoomba, Qld, Australia.

Coakes, S. J., Steed, L., and Price, J. (2008), SPSS Version 15.0 for Windows: Analysis without anguish, Australia, Brisbane: John Wiley and Sons. 
Dighe, A. (1995), Trends in adult education research in Asia, Adult Education and Development, 45, 81-94.

Hackett, R.D., Bycio, P., and Hausdorf, P.A. (1994), Further assessments of Meyer and Allen's (1991) three-component model of organization commitment, Journal of Applied Psychology, 79(1), 15-23.

Iverson, R. D., and Buttigieg, D. M. (1999), Affective, normative and continuance commitment: Can the 'right kind' of commitment be managed? Journal of Management Studies, 36(3), 307-341.

Jarvis, P. (2004), Adult education and lifelong learning: Theory and practice, New York: Routledge Falmer, 139-189.

Jarvis, P. (1995), Adult and continuing education: Theory and practice, London: Croom Helm.

Karakaya, F., and Barnes, N. G. (2010), Impact of online reviews of customer care experience on brand or company selection, Journal of Consumer Marketing, 27(5), 447-457.

Lam, A. (1992), Manpower needs and educational planning: An expert system or a system of experts. Paper presented at the International Conference on Continuing Higher Education in Hong Kong: Local Needs and International Networking into the Twenty-First Century, 6-8 January 1992, SPACE, The University of Hong Kong.

Ling, W., Fang, L., and Zhang, Z. (2002), Research on Chinese employees' organizational commitments, Social Sciences in China, 23(3), 59-67.

Lowe, J. (1982), The education of adults - A world perspective, London: Unesco Press.

Malhotra, N., Budhwar, P., and Prowse, P. (2007), Linking rewards to commitment: An empirical investigation of four UK call centres, The International Journal of Human Resource Management, 18(12), 2095-2128.

Malhotra, N. K. (2006), Marketing research: an applied orientation, 5th edition, London: Prentice Hall.

Mbokazi, B., Visser, D., and Fourie, L. (2007), Management perceptions of competencies essential for middle managers, Journal of Industrial Psychology, 30(1).

Meyer, J.P., and Allen, N.J. (1991), A three-component conceptualization of organization commitment, Human Resource Management Review, 1(1), 61-89.

Meyer, J. P., and Smith, C. A. (2000), HRM practices and organizational commitment: Test of a mediation model, Canadian Journal of Administrative Sciences, 17(4), 319-331. 
Meyer, J. P., Stanley, D. J., Herscovitch, L., and Topolnytsky, L. (2002), Affective, continuance, and normative commitment to the organization: A meta-analysis of antecedents, correlates, and consequences, Journal of Vocational Behavior, 61(1), 20-52.

Mezirow, J. (1991), Last gamble on education, Washington DC: Adult Education Association of the U.S.A.

Morton, R., and Newman, D. L. (1982), Barriers to part-time teaching: An evaluation of non-credit continuing education, Paper presented at the Evaluation Network Conference, Baltimore, U.S.A., October 1982.

Mowday, R. T., Steers, R. M., and Porter, L. W. (1979), The measurement of organizational commitment, Journal of Vocational Behavior, 14(2), 224-247.

Nunnally, J. C. (1989), Educational measurement and evaluation, New York: McGraw Hill.

Shin, H., Collier, D. A., and Wilson, D. D. (2000), Supply management orientation and supplier/buyer performance, Journal of Operations Management, 18(3), 317-333.

Sivadas, E., Kleiser, S. B., Kellaris, J., and Dahlstrom, R. (2003), Moral philosophy, ethical evaluations, and sales manager hiring intentions, Journal of Personal Selling and Sales Management, 23(1), 7-21.

Snape, E., and Chan, A. W. (2000), Commitment to company and union: Evidence from Hong Kong, Industrial Relations, 39(3), 445-459.

Streiner, D. (2003), Starting at the beginning: an introduction to coefficient alpha and internal consistency, Journal of Personality Assessment, 80, 99-103.

Sturges, J., Guest, D., Conway, N., and Davey, K. M. (2002), A longitudinal study of the relationship between career management and organizational commitment among graduates in the first ten years at work, Journal of Organizational Behavior, 23(6), 731-748.

Taormina, R. J. (1999), Predicting employee commitment and satisfaction: The relative effects of socialization and demographics, International Journal of Human Resource Management, 10(6), 1060-1076.

Wang, Y. (2004), Observations on the organizational commitment of Chinese employees: Comparative studies of state-owned enterprises and foreign-invested enterprises, International Journal of Human Resource Management, 15(4), 649-669.

Weaver, S. J. (2000), The relationship between administrators' perceptions of part-time faculty and utilization of part-time faculty at West Virginia public and private colleges and universities. West Virginia University unpublished Ed. D dissertation. 